\title{
Guest editorial: Organ trafficking and transplant tourism: a call for international collaboration
}

\author{
Alireza Bagheri · Francis L. Delmonico
}

Published online: 17 July 2013

(C) Springer Science+Business Media Dordrecht 2013

The thematic issue of the Journal of Medicine, Healthcare and Philosophy is dedicated to the global efforts to combat organ trafficking and transplant tourism. The negative impact of trafficking of human organs and transplant tourism on the application of transplant technology and the exploitation of the vulnerable people as organ providers has been documented worldwide (Gill et al. 2008; BudianiSaberi and Delmonico 2008; WHO 2010). As stated in the Declaration of Istanbul, "organ trafficking and transplant tourism violate the principles of equity, justice and respect for human dignity, ...transplant commercialism targets impoverished and otherwise vulnerable donors, it leads inexorably to inequity and injustice..." (Steering Committee of the Istanbul Summit. 2008).

The issue of exploitation of the vulnerable people through trafficking of human organs and transplant tourism is no longer a domestic but an international problem (Bagheri 2007). A comprehensive sustainable policy in fighting against organ trafficking and trade requires an international participation and global collaboration. It is crucial to find an innovative and realistic solution that can not only stop the migration of donors, recipients and human body parts across borders but also respect patients' desperate need and provide patients with a realistic alternative for transplantation.

It is the time to pay more attention to the link between human trafficking and trafficking of human organs. In fact, the definition of organ trafficking was derived from the

\footnotetext{
A. Bagheri ( $\square)$

Tehran University of Medical Sciences, Tehran, Islamic

Republic of Iran

e-mail: bagheria@yahoo.com

F. L. Delmonico

Harvard Medical School, Massachusetts General Hospital

Transplant Center, Boston, MA, USA
}

United Nations Protocol to Prevent, Suppress and Punish Trafficking in Persons, Especially Women and Children, in which the "removal of organs" is included as a key purpose of human trafficking (UN Protocol 2000). However, organ trafficking has yet to receive widespread international recognition as a criminal activity in the way that human trafficking has. In 2008, the Council of Europe and the United Nations agreed to prepare a "Joint Study on trafficking in organs, tissues and cells and trafficking in human beings for the purpose of the removal of organs". By upholding the principle of prohibition of making financial gains with the human body or its parts, the study identified the need to distinguish clearly between trafficking in human beings for the purpose of the removal of organs and the trafficking in human organs per se (Joint Council of Europe/United Nations study 2009). It worth to note that an extension of the precedent Council of Europe activity would be for the U.S. Congress to recognize human trafficking for the removal of an organ under the rubric of the Trafficking in Persons Report annually issued by the Department of State (US Trafficking in Person Report 2012).

No doubt, to solve a global problem, global collaboration is crucial. To this end, development of an international legally binding agreement to ban organ trafficking and trade and criminalization of organ trafficking is a step forward. This would not only prevent victimising the world's poor people as the source of organs for the rich, but also will protect organ recipients from unsafe organ transplantation.

In this international forum, six articles present national and international initiatives, experiences, and legislations to curb unethical practice of organ trafficking and transplant tourism.

In the first piece, Bagheri and Delmonico presents a summary of international initiatives to govern organ 
transplantation and trafficking, such as initiatives taken by the World Health Organization, UNESCO and the United Nations, the Declaration of Istanbul, as well as the Asian Task Force Recommendations in tackling organ trafficking and transplant tourism.

By presenting the international guidelines and recommendations, the paper calls for full implementation of those guidelines. The authors suggest that in order to prevent the exploitation of the poor as organ providers across countries, the development of an international legally binding agreement to criminalize organ trafficking is necessary.

In their contribution Budiani-Saberi and Columb present a rights-based approach in dealing with organ trafficking. They have stressed that tackling with trafficking of human organs and tissues, should not be reduced to a problem of supply and demand of organs for transplantation, or a problem of criminal justice and abandoned victims. Rather, the issue is at once an egregious human rights abuse and a form of human trafficking.

They suggest that this approach promote a better understanding of the phenomenon and provide a comprehensive framework with the capacity to protect vulnerable persons, and to prevent and suppress the organ trade. Such an approach calls States under International Human Rights Law (IHRL) to ensure, respect and fulfil their obligations to enforce measures to protect the welfare of their citizens, particularly those vulnerable to exploitation.

A comparative study between Israel and the Philippines, the former once an "exporter" of transplant tourists and the latter once an "importer" of transplant tourists presented by Padilla, Danovitch, and Lavee, describes the parallel changes that have taken place in recent years in these two countries. By providing the recent changes in the legal frameworks of organ transplantation and the positive symbiosis that developed between Israel and the Philippines, the paper shows the potential impact of legal measures to prevent transplant tourism.

The article by Linda Wright and her colleagues explains how Canadians continue to travel abroad to purchase kidneys despite ongoing international efforts to curb the practice. The data presented shows that transplant tourism is increasing in Canada, especially in British Columbia, which found that tourists made up nearly $10 \%$ of recipients. The paper touches upon an ethical dilemma when healthcare workers learn or suspect that a patient either is planning to embark on transplant tourism or has returned with a purchased kidney. A situation in which conflict revolves around the duty to care for a patient, and the fact that transplant tourism involves harms to others.

In another article, Farhat Moazam explains the collective efforts to pressure the government to bring about and implement a national law criminalizing organ trafficking and transplant tourism in Pakistan. By emphasizing the importance of understanding cultural values and social norms in tackling organ trade, the author argues that in order to prevent re-emergence of organ trafficking in the country the effort should focus on increasing the number of living related donors and establish robust deceased donor programs.

In the last article, De Castro shows how the Philippines became a destination for transplant tourism and how physicians were involved in the arrangement of transplant tourism under the so-called "packaged deals" in that country. It explains the positive impact of the new law in 2009 as well as the Declaration of Istanbul in stopping foreigners to traveling to the Philippines for human organs. The author sheds lights on the new problem of local transplant tourism and commercialism in human organs in the country and calls health authorities to address the problem of transplant tourism within national boundaries.

We believe this forum illuminates the complexity of the issues discussed in combating organ trafficking and transplant tourism and calls for a global orchestrated effort to implement practical measures to protect vulnerable people from exploitation while addressing the need of desperate patients to transplantation.

\section{References}

Bagheri, A. 2007. Asia in the spotlight of international organ trade: Time to take action. Asian Journal of WTO and International Health Law and Policy 2(1): 11-24.

Budiani-Saberi, D.A., and F.L. Delmonico. 2008. Organ trafficking and transplant tourism: A commentary on the global realities. American Journal of Transplantation 8(5): 925.

Gill, Jagbir, Bhaskara R. Madhira, Gjertson David, et al. 2008. Transplant tourism in the United States: A single-center experience. Clinical Journal of American Society Nephrology 3: $1820-1828$

Joint Council of Europe and United Nations study. 2009. Trafficking in organs, tissues and cells and trafficking in human beings for the purpose of the removal of organs. Available at: http://www. coe.int/t/dghl/monitoring/trafficking/Docs/News/OrganTrafficking study.pdf [last visited Jan. 12, 2013].

Steering Committee of the Istanbul Summit. 2008. Organ trafficking and transplant tourism and commercialism: The Declaration of Istanbul. The Lancet 372: 5-6.

UN Protocol 2000. Protocol to Prevent, Suppress and Punish Trafficking in Persons, especially Women and Children, Available at: http://www.uncjin.org/Documents/Conventions/dcatoc/final_ documents_2/convention_\%20traff_eng.pdf [last visited Jan. 12, 2013].

US Trafficking in Person Report. 2012. Available at: http://www. state.gov/j/tip/rls/tiprpt/ [last visited Jan. 2013].

WHO's Guiding Principles on Human Cell, Tissue and Organ Transplantation. 2010. Available at: http://www.who.int/trans plantation/Guiding_PrinciplesTransplantation_WHA63.22en.pdf [last visited Nov. 5, 2012]. 